\title{
VUORISTOKIIPEILYÄ KIELIVUORILLA
}

OLAVI JAMA(toim.) Kielivuori. Tarinoita kielen oppimises-

ta. Kansanvalistusseura, 2002.

Kansanvalistusseura järjesti viime talvena kirjoituskilpailun otsikolla "Tarinoita kielen oppimisesta". Kilpailussa haettiin omakohtaisia tekstejä ja tarinoita. Tarinoita haluttiin oppimisen iloista ja onnistumisista, mutta myös kielen opiskelun synkemmistä puolista. Aiheena saivat olla niin kielen opiskeluun löydetyt omat menetelmät kuin opiskelun toiveet, tavoitteet ja tulokset tai kielen opiskeluun vaikuttaneet opettajat, samoin kuin kielten oppiminen työssä ja käytännön elämässä, tai vaikkapa matkoilla sattuneet kielikommellukset.

Olavi Jaman toimittama kirja "Kielivuori - tarinoita kielen oppimisesta" esittelee kirjoituskilpailun satoa. 547 kilpailutekstin joukosta kirjaan on valittu 31 tekstiä, joista toimittaja on halunnut tehdä kokonaisuuden, joka kiinnostaa lukijoita sisäpiirien ulkopuolellakin. Tekstejä ei ole valittu kirjaan niiden pedagogisten tai tiedollisten ansioiden vuoksi, vaan valintakriteereinä on pidetty tekstien kertovaa otetta ja persoonallista kieltä. Kirjaan valikoituneet tekstit ovatkin luonteeltaan varsin erilaisia.

Otsikko Kielivuori viittaa Merita Nikkasen palkittuun kertomukseen, jossa hän vertaa kieltä vuoreen. Sen "juurelta karkea ja loiva, huipulta petollisen liukas. Kaukaa häikäisevän kaunis, lähempää toivottomuutta kylvävä." Kirjan tarinat kertovat kaikki omalla tavallaan tuon vuoren valloituksesta.
Teoksen luvut koostuvat kukin tarinoista, jotka tarkastelevat kielen oppimista enemmän tai vähemmän yhteisestä näkökulmasta. Esimerkiksi luvun Vieraille maille tarinat vievät lukijan kielimatkalle Puolaan, Italiaan, Viroon, Portugaliin ja Japaniin. Yhteistä näille kertomuksille on se, että kieli nähdään ensisijaisesti kommunikaation välineenä. "Kieli on työväline, mahdollisuus ja valtti”, toteaa Merita Nikkanen. Kieltä opitaan myös ihmissuhteiden kautta tai niiden vuoksi. Motivaatio kielen oppimiseen syntyy käytännön kokemuksista ja tarpeista. "Halusin ymmärtää enemmän niitä ihmisiä ja tajusin, että ensimmäinen askel on oppia heidän kieltään", kirjoittaa Jussi Kolehmainen omassa tarinassaan.

Monet lukujen otsikoista ovat varsin herkullisia, ja ne johdattelevat lukijaa luvussa aukeaviin näköaloihin.

\section{KIELI, MILTEI KUIN RAKKAUSSUHDE}

Kuu on feminiini -lukuun on koottu eläviä kuvauksia henkilökohtaisen suhteen syntymisestä kieleen. Näissä tarinoissa kieli herättää voimakkaita tunteita. Kieltä halutaan oppia sen itsensä vuoksi. Kielen oppiminen on kielileikkiä, maalailua, sanojen ja ilmausten maistelua. Kilpailun voittanut teksti, Leena Levannon "Sinun nimesi on..." kertoo koskettavasti siitä, miten kielen avulla voi omaksua kokonaan uuden maailman ja tavan ajatella. Levanto kuvaa kielen opiskelua kauniisti ja kunnioituksella: "Minun piti vakoilla sanoja, katsoa mitä ne puuhaavat omissa oloissaan, tavata ne erilaisissa askareissaan. Vasta kun opin tuntemaan ne joka puolelta, saatoin päästää ne lähelleni, ottaa ne omikseni. [...] mitä enemmän sanoja sain kerättyä, sitä kesymmiksi ne tulivat. Nyt sanoja on valtava lauma, joka vaeltaa vapaasti joka puolella. Ne tarjoutuvat auliisti ja iloisesti käytettäviksi." Humoristisemman kuvauksen antaa Mary Nurmisen kertomus suomen kielen oppimisesta savolaisessa pikkukaupungissa.

\section{LUURANKOJA KIELIKAAPISSA}

Kielen opiskelun varjopuolia kuvaa luku nimeltä Luuranko kielikaapissa. Luvun tarinat käsittelevät osuvasti monelle niin valitettavan tuttuja, karmaisevia kokemuksia kielen oppimisesta koulussa. Syyllistäviä, ilkeitä opettajia ja tuskantäyteistä kieliopin pänttäystä. Harmeja, vaikeuksia, uupumusta ja ahdistusta. Onneksi luku kuitenkin päättyy Eila Leskinen-Heilmanin tarinaan Traumasta intohimoon, joka kuvaa yhden ihmisen kehitystä traumatisoidusta koululaisesta innokkaaksi aikuiseksi kielenopiskelijaksi. Tarinan oivallus on, että jokaisen pitäisi itse löytää oma oppimistyylinsä, kehittää sitä ja olla motivoitunut. Kielihän on nähtävä vain kommunikaatiovälineenä ja virheet ovat sivuseikka. Tämä kertomus rohkaisee sekä meitä opettajia että niitä opiskelijoita, joihin kouluopetus on jättänyt lähtemättömät arvet. Aikuinenkin voi oppia oppimaan.

Luvussa Muotokuvia muis- 
tista esitellään mieleenjääneitä opettajapersoonia. On hämmästyttävää, kuinka vuosikymmenetkään eivät kykene haalistamaan suuria persoonallisuuksia, niin pahassa kuin hyvässä. Yhteistä näille kertomuksille on käsitys siitä, että hyvä opettaja on elävä persoona, oikeudenmukainen mutta vaativa, ja ehdottoman omistautunut asialleen. Piiskurit ja inkvisiittoritkin saavat synninpäästön, kun oppilas vuosien päästä havaitsee, että heidän oppinsa ovat vielä hyvässä muistissa.

Koska tekstien valinnassa on kiinnitetty huomiota erityisesti persoonalliseen, kertovaan otteeseen ja kaunokirjallisiin ansioihin, ja kirjoituskilpailun teema jätettiin tarkoituksellisesti hyvin avoimeksi, kirjaan on valikoitunut tekstejä, jotka edustavat sekä tyylillisesti että sisällöllisesti jonkinlaisia ääripäitä. Kirjasta löytyy kuvauksia henkilökohtaisista "oppimishistorioista", joista välittyy sisukkuutta, innostusta, ihmettelyä ja suurta sivistystä. Toisaalta on myös huumorilla höystettyjä kertomuksia enemmän tai vähemmän epäonnistuneista seikkailuista kielten maailmassa.

Tekstien erilaisuus on sekä teoksen vahvuus että sen heikkous. Heikkous, koska kirja vaikutti ainakin ensilukemalla sirpaleiselta, eikä tekstien sijoittelu aina tuntunut johdonmukaiselta. Vahvuus, koska erilaiset kertomukset kuitenkin valottavat kielenoppijan maailmaa monelta suunnalta, raikkaasti ja monipuolisesti.

Ääripäistä huolimatta monissa kirjoituksissa toistuvat kouluahdistus, sen voittaminen ja oivallus, että kielen oppiminen vaatii sen jatkuvaa aktiivista työstämistä ja käsittelyä. Jussi
Kolehmainen toteaa omassa tarinassaan: "Mieleeni jäi ... paljon sanoja, joiden merkitystä en ymmärtänyt, mutta löytämisen riemu oli melkoinen kun sitten myöhemmin kuulin jonkin noista sanoista jossakin keskustelussa ja asiayhteydestä ymmärsin sen, mitä se tarkoittaa." Löytämisen riemustahan kielen oppimisessa on pitkälti kysymys!

Kirjan tekstit osoittavat taas kerran, että kielen oppiminen on pohjimmiltaan elämyksellistä ja että se johtaa parhaimmillaan uusien maailmojen avautumiseen uusiin kulttuureihin, maihin ja ihmisiin tutustumisen kautta. Raimo Mäkelä lainaa tarinassaan saksalaista kielifilosofia Johann Georg Hamannia: "Se mikä [vieraiden kielten opettelemisessa] näyttää olevan pelkkää muistin toimintaa, onkin kaikkien sielunvoimien ja korkeampien, tärkeämpien, vaikeampien, jopa hengellisten asioiden valmistamista ja harjoittelemista. Ellei opeteta tällä tavalla, kielistä tulee hyvin vaikeita, kuivia ja vastenmielisiä, turhia ja hyödyttömiä."

Tarinat tarjoavat niitä lukevalle opettajalle mahdollisuuden pohtia omaa toimintaansa. Millaisen kuvan kielestä minä haluan välittää opiskelijoille? Ja miten ihmeessä toimin niin, että edes pieni osa tästä valtavasta kokonaisuudesta avautuisi myös luokkahuoneessa? Leena Levanto ehdottaa omassa tarinassaan, että kielen oppimiseen tarvitaan paitsi "oppikirjojen puisevaa todellisuutta ja kieliopin rakennustelineitä”, myös "ennen kaikkea sellaisten opettajien opastusta, joilla oli itsellään elävä, lämmin suhde kieleen. Joiden mielestä kieli ei ole vain jotakin ulkokohtaista, joka tungetaan oppilaan päähän.
Joille kielen opettaminen ei ole virheiden karsimista ja niillä säikyttelyä, osaaminen ei ole jokotai-ilmiö eikä kielen omaksuminen tekninen suoritus, vaan jokaisen oppijan omakohtainen matka kohti hiukan uudenlaista maailman jäsentämistä." Harmi vain, että todellisuus muistuttaa välillä Tiina Lehtorannan kertomusta Opettaja nörttimaassa. Tämä kertomus kuvaa humoristisesti sitä maailmojen yhteentörmäystä, joka syntyy kun innokas, valveutunut englannin opettaja kohtaa ryhmän kiireisiä sovellusinsinöörejä.

Millä tavalla kieltä opitaan, millaisia ovat onnistuneet tai epäonnistuneet oppimisstrategiat? Tämä kirja ei ole tieteellinen teos, eikä sen tarkoitus ole vastata kertomusten pohjalta herääviin moniin kysymyksiin. Kilpailutekstit muodostavat kuitenkin jännittävän, laaja-alaisen tutkimusaineiston, joka on jo käytössä Jyväskylän yliopiston Soveltavan kielentutkimuksen keskuksessa. Onkin mielenkiintoista nähdä, millaista tutkimusta aineistosta syntyy. Olisipa myös kiinnostavaa verrata näiden kertomusten maailmaa opettajan maailmaan, siihen, millaisena opettaja näkee roolinsa ja tehtävänsä.

Oppilaitosten arki erilaisine arviointihankkeineen, strategioineen ja OPS:ineen saa tästä voimakkaita henkilökohtaisia oppimiselämyksiä kuvaavasta tarinakokoelmasta oivan vastapainon. Teoksessa näyttäytyviin oppijoihin täytyy suhtautua ihmetellen ja kunnioituksella. Opettajana olen etuoikeutettu saadessani todistaa kielivuoren valloitusta.

\section{Johanna Garant}

